Rafał TOCZKO

(Toruń, UMK)

\title{
PELAGIUSZ WIDZIANY OCZAMI ŚW. AUGUSTYNA, ŚW. HIERONIMA, PAWŁA OROZJUSZA I MARIUSZA MERCATORA
}

Do wszystkich pism skierowanych przeciw Pelagiuszowi, autorstwa czterech wymienionych w tytule pisarzy, możemy odnieść uwagę Ilony Opelt dotycząca pism polemicznych Hieronima, stwierdzając, że są to pisma okolicznościowe (die Gelegenheitschriften), bo stanowią często szybką i spontaniczna, reakcję na to, co zaszło ${ }^{1}$. Jedne mogą być komentarzem do konkretnego wydarzenia, jak De gestis Pelagii z 417 r., Epistula 175 i Sermo 348A (416 r.) Augustyna, czy Liber apologeticus Pawła Orozjusza z 415 r., inne zaś mają ostudzić zapał konkretnych adresatów wobec Pelagiusza, jak pisma Hieronima, czy niektóre listy Augustyna: 157 (415 r.), 186 (417 r.), 194 (418 r.); są wśród nich i takie, które służą odparciu konkretnego pisma przeciwnika, jak De natura et gratia Augustyna z 415 roku. Natomiast De gratia Christi et peccato originali z 418 r. jest stanowczą odpowiedzią Hippończyka na próbę mediacji w sprawie Pelagiusza ze strony trójki rzymskich arystokratów: Melanii Młodszej, Piniana i Albiny². Ten okolicznościowy charakter rozpatrywanych przeze mnie tekstów utrudnia poniekąd ich systematyzację. Ponieważ jednak nie traktuję tu o nich in extenso, lecz analizuję jedynie pewien ich aspekt, tj. portret heretyka w nich zawarty, jesteśmy w stanie uchwycić i przedstawić zarówno podobieństwa, jak i różnice zachodzące między nimi. Takie zestawienie pozwoli przede wszystkim uwypuklić swoistość technik polemicznych każdego z autorów, ale także wskazać konwencjonalne cechy heretyka.

Analizowane dzieła różnią się także ciężarem gatunkowym. Książeczka Pawła Orozjusza nie odegrała w okresie życia Pelagiusza większej roli, poza tym, że była znana biskupom Afryki Północnej, a i dziś jest tekstem rzadko czytanym czy tłumaczonym. Księgi Hieronima wymierzone w tego heretyka odegrały ważną rolę $\mathrm{w}$ procesie formowania opinii na temat Pelagiusza na

\footnotetext{
${ }^{1}$ Por. I. Opelt, Hieronymus Streitschriften, Heidelberg 1973, 155.

${ }^{2}$ Por. Augustinus, De gratia Christi I 1, 1, CSEL 42, 125. Należeli oni do grona możnych patronów tego mnicha, zob. P. Brown, Pelagius and his supporters: aims and environment, JTS 19 (1968) 93-114; tenże, The rise and function of Holy Man in late antiquity, JRS 61 (1971) 80-101.
} 
cesarskim dworze Honoriusza ${ }^{3}$. Pisma Mariusza Mercatora zostały przygotowane przed soborem w Efezie, jako dossier błędów Celestiusza i Juliana z Eklanum, w których znajdujemy takie elementy biografii Pelagiusza. Dzieła Augustyna stały się podstawą wyroków cesarza Honoriusza i synodów biskupów afrykańskich, uznających Pelagiusza za heretyka, do dziś stanowią też podstawę opinii na temat jego życia i poglądów. Kiedy Pelagiusz przegrał ostatecznie walkę o swoje dobre imię, Augustyn został zaszczycony rzadkim komplementem, bo pochodzącym od samego Hieronima:

„Zawsze, jak się godziło, szanowałem Twoją Świątobliwość [...]. Teraz zaś dodaję coś do pełnego i pełne uzupełniam, aby mi ani jedna godzina nie przeszła bez wspomnienia twojego imienia. Ty bowiem wytrwałeś w gorącej wierze przeciw wiejącym wiatrom i wolałeś, o ile to było w twojej mocy, sam jeden uwolnić się z Sodomy niż pozostać razem z ginącymi. Przy roztropności twojej wiesz, co powiem: Dobrze się spisałeś! Masz uznanie w świecie. Katolicy cię szanują jako odnowiciela dawnej wiary i patrzą na ciebie; heretycy cię nienawidza, co jest oznaką największej chwały."

Poniżej opisuję szczegółowo elementy portretu Pelagiusza u Hieronima, Pawła Orozjusza i Mariusza Mercatora, za każdym razem porównując je do charakterystyki zawartej w dziełach Augustyna. Nie przedstawiam tu pełnej charakterystyki Pelagiusza w dziełach Augustyna, a jedynie podkreślam jej najważniejsze cechy. Dokładne omówienie tego zagadnienia rozsadziłoby ramy artykułu, a zainteresowany czytelnik znajdzie je w innej mojej pracys.

\section{PELAGIUSZ U HIERONIM I AUGUSTYNA}

1. Różnice. Hieronimowe pisma: List do Ktezyfonta (133), List do Cypriana $(140)^{6}$, Dialog przeciw pelagianom ${ }^{7}$ oraz Komentarz do ksiegi Jeremi-

\footnotetext{
${ }^{3}$ Por. Augustinus, Epistula 19*, 2, ed. J. Divjak, CSEL 88, 91-92; zob. też G. Caruso, Girolamo antipelagiano, „Augustinianum” 49 (2009) 83-89.

${ }^{4}$ Hieronymus, Epistula 141, 1 (= Augustinus, Epistula 195), PL 22, 1180, tłum. J.Czuj: Św. Hieronim, Listy, III, Warszawa 1954, 411-412.

${ }^{5}$ Por. R. Toczko, Jak zostać heretykiem. Przypadek Pelagiusza, Toruń 2012; zob. też ŹMT 15, 129-167 (Bibliografia: Pelagiusz i pelagianizm).

${ }^{6} \mathrm{O}$ antypelagiańskim wydźwięku tego tekstu jako pierwszy pisał F. Cavallera: S. Jérôme. Sa vie et son oeuvre, II, Louvain 1922, 69-70. Argumentację tę rozwinął C. Moreschini: Il contributo di Girolamo alla polemica antipelagiana, CNS 3 (1982) 61-71.

${ }^{7}$ Por. Hieronymus, Dialogus adversus Pelagianos, PL 23, 495-590, tłum. W. Szołdrski, PSP 10, Warszawa 1973, 69-193. We wstępie do najnowszego wydania C. Moreschini (Dialogi adversus Pelagianos libri tres, ed. C. Moreschini, CCL 80, Turnhout 1990) stosuje tytuł Dialogus adversus Pelagianos. Jednak w tytułach poszczególnych części, w rękopisach zachowały się tytuły: Dialogus Attici et Critoboli compositus; Altercatio: Attici orthodoxi et Cretoboli heretici; Attici Hieronymi et Cretoboli Pelagii; Catholici supra Attici et heretici supra Critoboli. Hieronim nie wymienia imienia Pelagiusza, a osoba głosząca jego poglądy nazwana została Kritobulem. Nie ulega wątpliwości, że Dialogus adversus Pelagianos nie jest oryginalnym tytułem. Potwierdza to świadectwo Juliana
} 
asza z ok. 415 r., zawierają wiele odniesień do Pelagiusza i jego poglądów. Badacze twórczości tego niezwykle płodnego pisarza podkreślają relatywną łagodność tych pism w stosunku do wcześniejszych jego polemik. Należy jednak zauważyć, że wartościowanie to jest mało dla nas użyteczne, bowiem łagodność Hieronima, to dla wielu innych wciąż szczyt agresji. Nawet w tych „delikatnych” dyskusjach z nowym heretykiem zapalczywy mnich nie stroni od inwektywy, obelgi, czy ironii. Jakkolwiek nie ujawnia imienia Pelagiusza, to sprawia, że każdy wie dokładnie o kim jest mowa ${ }^{8}$. Nadaje swojemu przeciwnikowi znaczące etykiety-wyzwiska, nazywając go $\operatorname{canis}^{9}$, przypisując mu stultitiam impudentiae copulatam ${ }^{10}$. Są one pełnoprawnym, choć zwięzłym argumentem a persona; charakteryzują bowiem Pelagiusza nie per se, lecz po to, aby pokazać, że jest on heretykiem. To znaczy, np. że, jak każdy heretyk, jest on podobny do dzikich zwierząt, do filozofów pogańskich, do wcześniejszych heretyków, etc. Ta skłonność do nadawania etykiet jest charakterystyczna dla inwektywy i dla polemik Hieronima ${ }^{11}$. Augustyn w dyskusji z Pelagiuszem znacznie rzadziej ucieka się do tak osobistej napaści.

Hieronim, inaczej niż Augustyn, nie uważa herezji Pelagiusza za specjalną nowinę ${ }^{12}$. Dla Augustyna Pelagiusz jest herezjarcha, nie tylko heretykiem, a to znaczy - twórcą herezji i przywódcą heretyckiej grupy ${ }^{13}$. Hieronim natomiast zarzuca heretykowi kontynuowanie nauk filozofów i heretyków - argument znany choćby z pism Tertuliana ${ }^{14}$. Doszukuje się w doktrynie Pelagiuszowej echa filozoficznych poglądów stoików i pitagorejczyków, a nawet jego „współdomownika Porfiriusza” ${ }^{15}$. Zarzuca Pelagiuszowi głoszenie nauki o apatheia (impassibilitas), a zatem o możliwości ,wyzbycia się namiętności” i o anamartesia (impeccantia), tj. możliwości bycia „,bezgrzesznym”, których

z Eklanum (Augustinus, Opus imperfectum IV 87), gdzie przyznaje, że czytał Dialog Hieronima, w którym postacie noszą imiona Krytobul i Attyk, a następnie pyta Augustyna: „Który to katolik jest atakowany w Dialogach? Kto przygniatany przez Hieronima ciężarem Pisma, jeśli nie Pelagiusz?”

${ }^{8}$ Por. Augustinus, Epistula 19*, ed. J. Divjak, CSEL 88, 93.

${ }^{9}$ Por. Hieronymus, Dialogus adversus Pelagianos III 6, CCL 80, 105: „Quaerit hoc Marcion et omnes haereticorum canes".

${ }^{10}$ Por. tamże I 32, CCL 80, 40: „non intelligis stultitiam tuam impudentiae copulatam”.

${ }^{11}$ Por. B. Jeanjean, Saint Jérôme et l'hérésie, Paris 1999, 390-403, który omawia kolejno poszczególne zarzuty Hieronima i ich trafność; S. Seliga, Quibus contumeliis Hieronymus adversarios carpserit?, „Eos” 34 (1932-1933) 395-412; tenże, De invectiva Hieronymiana, CT 16 (1935) 145-181; W. Süss, Der heilige Hieronymus und die Formen seiner Polemik, „Giessener Beiträge zur deutschen Philologie” 60 (1938) 212-238; S. Longosz, Zarys historii inwektywy wczesnochrześcijańskiej, RTK 43 (1996) z. 2, 363-390 (bibliografia); tenże, Inwektywa, EK VII 413-417.

${ }^{12}$ Por. Augustinus, Sermo 348A, 5; Epistulae 178, 1; 186.

${ }^{13}$ Por. Augustinus, Contra duas epistulas Pelagianorum IV 8, 21; De nuptiis et concupiscentia II 5, 15; Contra Juliani responsionem imperfectum opus II 8 i II 66.

${ }^{14}$ Por. Tertullianus, Adversus Hermogenem 8, 3; De anima 3, 1; podaję za C. Moreschini (Il contribuito, s. 66).

${ }^{15}$ Por. Hieronymus, Epistula 133, 1-2 i 9, PL 22, 1148-1158. 
twórcami - zdaniem Hieronima - byli Pitagoras i Zenon ${ }^{16}$, a kontynuatorami Orygenes i jego ,uczniowie”, Rufin z Akwilei, Ewagriusz, Jowinian ${ }^{17}$. Hieronim, który w $415 \mathrm{r}$. ma już za sobą zerwanie i kampanię oskarżeń przeciw dawnemu przyjacielowi Rufinowi z Akwilei, w Komentarzu do księgi Jeremiasza nazywa Pelagiusza jego uczniem. Czyni to za pomocą aluzji - nie nazywając żadnego z nich po imieniu - Rufin jest tu „Grunniusem”, a Pelagiusz jego uczniem, nieuczonym oszczercą ${ }^{18}$.

Tego typu argumentacji nie znajdziemy u Augustyna, który podkreśla oryginalność tej herezji, jej nowość - zyskując w ten sposób przychylność i uwagę adresatów swoich pism. Po pierwsze, musieli mu być wdzięczni za to, że ostrzega ich przed nowym, a więc nieznanym niebezpieczeństwem. Po drugie, sam Augustyn wspomina o tym, że najnowsza herezja uchodziła za najgorszą ${ }^{19}$; pismo przeciw autorowi nowej herezji wzbudzać musiało zrozumiałe emocje. Biskup Hippony milczy także o sposobie, w jaki herezjarcha zjednywał sobie uczniów i zyskiwał przychylność możnych. Raz jedynie wspomina o wyjątkowej wymowności i wdzięku jego pism² ${ }^{20}$. Popularność i liczebność uczniów Pelagiusza są ważnymi faktami, których przyczyny nie są jednak przedmiotem tego artykułu ${ }^{21}$.

Hieronim, z godziwie odmierzoną szczyptą złośliwości, podkreśla w takim wypadku nie tylko zdolności krasomówcze, ale również skłonność herezjarchy do nadużywania komplementów wobec możnych, zwłaszcza kobiet. Wyśmiewa też jego talent do zjednywania sobie sympatii płci przeciwnej - co zawsze jest dobrym argumentem przeciwko ascecie ${ }^{22}$. Przedstawia go jako pochlebcę otoczonego zastępem amazonek ${ }^{23}$. W pismach Hieronima znajdziemy także charakterystykę wyglądu fizycznego Pelagiusza, której brak w twórczości Augustyna. Autor Dialogu, podobnie jak Orozjusz, nie szczędzi mu uszczypliwości. Jego zdaniem ten „tępak, który spasł się na szkockich

${ }^{16}$ Por. Hieronymus, Epistula 133, 1, PL 22, 1148.

${ }^{17}$ Por. Hieronymus, In Hieremiam prophetam IV 1, 2; Epistula 133, 3. Zarzuty te nie są dobrze uzasadnione, Pelagiusz bowiem otwarcie występował przeciw Jowinianowi, a Rufin był nie mniej uzależniony od myśli Orygenesa niż sam Hieronim. Poszczególne elementy doktryny Pelagiusza, które dotarły do nas za pośrednictwem pism Hieronima, omawia B. Jeanjean (Saint Jérôme, s. 252-261).

${ }^{18}$ Por. Hieronymus, In Hieremiam prophetam. Prologus 1.

${ }^{19}$ Por. Augustinus, Sermo 183, 5-13; Leo I papa, Sermo 24, 5; 28, 4.

${ }^{20}$ Por. Augustinus, Epistula 188, 3, 13, PL 33, 853: „Satis enim dici non potest, quantum cupiamus in eorum hominum scriptis, qui propter acrimoniam atque facundiam leguntur a plurimis, apertam confessionem illius gratiae reperiri”.

${ }^{21}$ Augustyn wielokrotnie powtarza, że Pelagiusz łatwo zjednuje sobie zwolenników, którzy są liczni, por. De gestis Pelagii 35, 62; Epistulae 186, 8, 29; 188, 2-3.

${ }^{22}$ Por. Hieronymus, Epistula 133, 4. Być może zdradza też zazdrość samego Hieronima.

${ }^{23}$ Por. Hieronymus, Dialogus I 26, CCL 80, 33: „Verum tu tantae es liberalitatis et favorem tibi apud Amazonas tuas concilias, ut in alio loco scripseris: «scientiam legis etiam feminas habere debere», cum Apostolus doceat tacendum esse mulieribus in Ecclesia et, si quid ignorant, domi viros suos debere consulere". 
zacierkach"24 poruszał się ,żółwim krokiem”25. Z niewiadomego powodu naśmiewa się także z czoła heretyka, które wyglądało, jego zdaniem, jak rogi. Być może to również jest aluzja do otyłości mnicha z Brytanii ${ }^{26}$.

Hieronim nadał postaci Krytobula, jednego z dwóch uczestników Dialogu, tożsamość Pelagiusza. Krytobul wygłasza między innymi sądy zaczerpnięte z pism herezjarchy, ale zdecydowana większość jego wypowiedzi, to efekt nieskrępowanej wolności twórczej autora tej fikcji literackiej. Jakkolwiek jasnym jest, że Krytobul to porte parole Pelagiusza, osoba heretyka kryje się w literackiej postaci. Ponadto, dialog ten jest bliższy diatrybie niż prawdziwemu przedstawieniu poglądów Pelagiusza - jak pisze jeden z francuskich badaczy ${ }^{27}$. Ten charakter utworu sugeruje, że jego autor chciał uzyskać efekt dystansu właściwy dla dzieła literackiego. W związku z tym Hieronim jeszcze mniej musiał trzymać się prawdy o historycznym Pelagiuszu niż Augustyn. Gdyby na cesarskim dworze sprzyjano mnichowi z Brytanii, Hieronim, jako autor Dialogu, mógłby zaprzeczyć, że to jego osobę ukrył pod postacią Krytobula.

2. Podobieństwa. Hieronim, podobnie jak Augustyn, podkreśla braki intelektualne Pelagiusza i jego niedokształcenie. W Dialogu wytyka porte parole Pelagiusza słabą pamięć, ponieważ tamten jakoby zapomniał o tym, co w rozmowie zostało już ustalone ${ }^{28}$. Podobnie czyni Augustyn, kiedy wykazuje sprzeczności w rozumowaniu Pelagiusza ${ }^{29}$. Wyśmiewa go także jako ucznia Rufina z Akwilei, za nieznajomość dzieł swojego nauczyciela. Pelagiusz krytykując Hieronima - zdaniem samego atakowanego - używał tych samych argumentów, co jego nauczyciel, chociaż powinien wiedzieć, że zostały one już dawno odparte ${ }^{30}$.

Cechą, która łączy portret Pelagiusza, zawarty w dziełach obu pisarzy, jest jego nieporadność retoryczna ${ }^{31}$. Krytyka autorstwa Hieronima jest jed-

${ }^{24}$ Hieronymus, In Hieremiam prophetam. Prologus 4, CCL 74, 2: „stolidissimus et Scottorum pultibus praegravatus".

${ }^{25}$ Por. Hieronymus, Dialogus adversus Pelagianos III 16, CCL 80, 120: „testudineo incedens gradu".

${ }^{26}$ Por. tamże I 30, CCL 80, 38: „ut cum Moyse in nube et caligine facie ad faciem audias verba Dei et inde nobis cornuta fronte procedas". Zdaniem R.F. Evansa (Pelagius: inquiries and reappraisals, New York 1968, 34-35) należy tę uwagę czytać razem z informacją Orozjusza (Liber apologeticus 31) o tym, że Pelagiusz nawet nad brwiami miał tłuszcz, i proponuje uznać, że heretyk miał zdeformowane czoło.

${ }^{27}$ Por. Jeanjean, Saint Jérôme, s. 252.

${ }^{28}$ Por. Hieronymus, Dialogus adversus Pelagianos III 6.

${ }^{29}$ Por. Augustinus, De natura et gratia 54, 63.

${ }^{30}$ Por. Hieronymus, In Hieremiam prophetam. Prologus 3-4, CCL 74, 1-2: „Ut nuper indoctus calumniator erupit, qui commentarios meos in epistulam Pauli ad Ephesios reprehendendos putat. [...] quod non videns praecursor eius grunnius olim nisus est carpere, cui duobus respondi libris".

${ }^{31}$ Piszę o tym obszernie w: R. Toczko, Heretic as bad rhetorician: how Augustine discredited Pelagius, AugSt 42 (2011) 211-231. 
nak bardziej powierzchowna i obecna właściwie w kilku efektownych sformułowaniach, których ironia zbliża portret Pelagiusza do satyrycznej karykatury. Tak m.in. jest, kiedy mówi on o cycerońskich frazach Pelagiusza, które wszędzie rozpoznaje ${ }^{32}$, jak również kiedy wypomina pelagianom

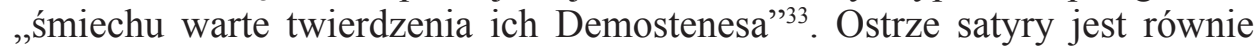
groźne w ręku biskupa Hippony, gdy pisze:

„O czym więc on tutaj mówi i za pomoca jakich prawideł [sztuki retorycznej]

próbuje przekonywać o tym, nad czym nie zechciał się zastanowić?"34.

Hieronim, tak samo jak Augustyn, zarzuca Pelagiuszowi przebiegłość i skrytość, sugerując, że innych nauk udziela swoim uczniom, a co innego głosi na zewnątrz ${ }^{35}$. Nakazuje mu wręcz głosić publicznie to samo, co wykłada $\mathrm{w}$ tajemnicy ${ }^{36}$. Zarzuca Pelagiuszowi, że on i jego poplecznicy z łatwością wypierają się swoich poglądów albo je przemilczają, co wyróżnia ich w oczach Hieronima - oczywiście pod względem niegodziwości - nawet wśród najgorszych heretyków ${ }^{37}$. Te same cechy heretyka odnajdziemy również w twórczości biskupa Hippony, choć on najczęściej podkreśla zdolność do przebiegłego reinterpretowania swoich poglądów i ukrywania ich w niejasnych sformułowaniach ${ }^{38}$.

Wreszcie, w dziełach obu polemistów jedną z podstawowych cech Pelagiusza jest jego zepsucie moralne. Objawia się ono, jak u wszystkich heretyków, przede wszystkim jako superbia oraz impudentia ${ }^{39}$. Pycha wiąże się ze stultitia $\mathrm{w}$ parę cech, z których obie mogą być swoim uzasadnieniem: heretyk jest głupi, bo jest pyszny, a zarazem jest pyszny właśnie dlatego, że jest głupi. Chociaż jest to argument o strukturze kolistej i jako taki może być uważany za błędny, miał on dużą siłę przekonywania. Nie czerpał on bowiem swojej mocy argumentacyjnej z poprawności wynikania wniosku z przesłanki, ale z odwołania się do topicznych cech heretyka i znanej czytelnikom konwencji inwektywy. Rozumowano tak: jeśli wykaże się, że heretyk występuje przeciw

${ }^{32}$ Por. Hieronymus, Dialogus adversus Pelagianos III 16, CCL 80, 120: „Quae duo capitula orationis et laudis soles cum tuis iurare discipulis non esse tua, cum perspicue stili tui splendor eluceat, et tanta sit venustas eloquii Tulliani, ut testudineo incedens gradu, quae secreto doces mittisque venalia, publice non audeas proferri”.

${ }^{33}$ Tamże II 4, CCL 80, 59. Chociaż być może mówiąc o Demostenesie ma on na myśli Celestiusza, por. G. Honnay, Caelestius discipulus Pelagii, „Augustiniana” 44 (1994) 271-302.

${ }^{34}$ Augustinus, De natura et gratia 49,57, PL 44, 274, thumaczenie własne.

${ }^{35}$ Por. Hieronymus, Epistula 133, 3; Augustinus, De gratia Christi I 22, 23; Epistula 194, 10 , 46. W tym ostatnim tekście Augustyn przypisuje Pelagiuszowi „wilkołaczą przebiegłość”.

${ }^{36}$ Por. Hieronymus, Epistula 133, 11.

${ }^{37}$ Por. tamże.

${ }^{38}$ Por. Augustinus, Epistula 19*, 2, CSEL 88, 92-93; De gestis Pelagii 11, 24-26; De gratia Christi I 12, 13.

${ }^{39}$ Por. Hieronymus, Dialogus adversus Pelagianos III 14, 19-20; Jeanjean, Saint Jérôme, s. 409-411. Augustyn niezwykle często podkreśla pychę Pelagiusza, zob. np. Augustinus, De natura et gratia 29, 33 i passim; Sermo 163, 11; 163A, 3; 348A, 4; Enarrationes in Ps. 31, 2, 10; 45, 13, 15. 
Bogu, (albo przeciw Biblii, bądź przeciw nauce Kościoła) to znaczy, że jest głupcem i pyszałkiem, gdyż tylko głupiec i pyszałek może wystąpić przeciw Bogu i Kościołowi. Nie zawsze niepoprawny logicznie argument musiał być słaby, zwłaszcza jeśli poparty był autorytetem piór tej miary, co Hieronim czy Augustyn. W Dialogu Strydończyka znajdziemy również zarzut, że Pelagiusz przyznaje się do grzechu jedynie z powodu fałszywej pokory ${ }^{40}$, który później eksploatuje Augustyn.

\section{PELAGIUSZ U OROZJUSZA I AUGUSTYNA}

1. Różnice. Inaczej niż Augustyn, a podobnie jak Hieronim, Orozjusz w swoim Liber apologeticus przyjmuje, że w Pelagiuszu i Celestiuszu żyją i przez nich przemawiaja zmarli już heretycy: Orygenes, Pryscylian i Jowin$i^{41}$; czyni też zadość konwencji pism antyheretyckich, uciekając się do tego często spotykanego oskarżenia. Nie ma on jednak tego autorytetu, jakim cieszą się w społeczności chrześcijan Augustyn czy Hieronim, dlatego też i portret heretyka, który przedstawia, jest inny. Afektowana skromność, konwencjonalna u starożytnych pisarzy, nie pojawia się w pismach Augustyna, kiedy porównuje on Pelagiusza do siebie. Tymczasem Orozjusz przedstawia Pelagiusza jako Goliata, choć nie ma, jak wyznaje, śmiałości nazwać siebie Dawidem $^{42}$. Ukrywa się za autorytetem Augustyna i Hieronima, których nazywa patres ${ }^{43}$, columnae et firmamenta Ecclesiae catholicae ${ }^{44}$, pozostawiając dla siebie tytuł „moja znikomość” (pusillitas mea) ${ }^{45}$.

${ }^{40}$ Por. Hieronymus, Dialogus adversus Pelagianos I 29.

${ }^{41}$ Orosius, Liber apologeticus contra Pelagianos 1, 5-6, CSEL 5, 604: „Nam Origenes et Priscillianus et Iovinianus, olim apud se mortui, in his vivunt, et non solum vivunt verum etiam loquuntur; nunc vero Pelagius et Caelestius, si in his perseveraverint viventes mortui, ecce adversus Ecclesiam, quod miserum est, et, quod multo miserius est, in Ecclesia palam sibilant impii que serpentes vibrantibus infecta linguis ora lambentes dum sanctam et munitissimam sedem cui subtiliter inrepsere obsident, cunctos fideles, ne ad illud firmissimum quondam in Sion refugium convolemus, exterrent".

${ }^{42}$ Por. tamże 3, 1, CSEL 5, 606: „Ne, quaeso, beatissimi sacerdotes, quisquam me arbitretur sub praetextu speciei Goliath David nomine gloriari: vos me participem certaminis vestri esse voluistis, ut auxiliator non auctor accederem".

${ }^{43}$ Por. tamże 5, 1 i 3, CSEL 5, 609: „Responsum saepissime est ab universis: «nos accusatores huius non sumus, sed quid fratres tui, patres nostri, senserint et decreverint super hac haeresi, quam nunc laicus vulgo praedicat, intimamus, ne Ecclesiam, tuam praesertim ad cuius sinum convolavimus, te ignorante conturbet» [...]. Patres, quos universa per orbem Ecclesia probat, quorum communioni vos adhaerere gaudetis, damnabilia haec esse dogmata decreverunt: illis probantibus nos oboedire dignum est".

${ }^{44}$ Por. tamże 1, 4, CSEL 5, 604: „Patres enim et qui iam quieverunt martyres et confessores, Cyprianus, Hilarius et Ambrosius, et quibus etiam nunc permanere adhuc in carne necessarium est, qui sunt columnae et firmamenta Ecclesiae catholicae, Aurelius Augustinus et Hieronymus, multa iam adversus hanc nefariam haeresim absque designatione nominum haereticorum scriptis probatissimis ediderunt".

${ }^{45}$ Por. tamże 3, 3, CSEL 5, 606-607: „Ilico a pusillitate mea postulastis universi, ut si quid super 
Orozjusz, tak jak Hieronim, a inaczej niż Augustyn, kpi także z wyglądu heretyka. Sugeruje, że Pelagiuszowi tak łatwo jest unieść ciężar bezgrzeszności, gdy zwraca się do niego:

„wykarmiony na ucztach i [wypielęgnowany] w kapielach, plecy masz szerokie, a kark silny, obnosząc swoją tłustość nawet na czole ${ }^{46 "}$.

Nazywa go minister mensarum ${ }^{47}$ - co daje się zrozumieć jedynie w kontekście uwag Hieronima o obżarstwie i otyłości Pelagiusza ${ }^{48}$.

Augustyn nie czynił zarzutu z pochodzenia Pelagiusza. Jakakolwiek jednak była tego przyczyna, to nie powstrzymała ona Orozjusza od wygłaszania iście Hieronimowych uszczypliwości pod adresem heretyka. Kiedy Orozjusz krytykuje styl wypowiedzi Pelagiusza, to w złośliwy sposób uzasadnia ten jego mankament: $\mathrm{z}$ powodu niskiego urodzenia nie miał on możliwości zdobycia wykształcenia, $\mathrm{z}$ tego samego względu brak mu także naturalnego dobrego smaku ${ }^{49}$. Pochodzenie zawsze było dobrą podstawą argumentacji, do której szczególnie często odwoływano się tworząc nagany oraz pochwały. Nie stroni od niego Hieronim, ale Augustyn nie wykorzystuje go w dyskusjach z Pelagiuszem.

Orozjusz podważa też autorytet Pelagiusza jako ascety. Zarzuca mu spotykanie się z ludźmi możnymi i bogatymi pod pozorem praktyk religijnych ${ }^{50}$, sugerując, że w takich sytuacjach nie zawsze służył on prawdzie, a nierzadko zdarzało mu się też pochlebstwo. Przypomina to charakterystykę obłudnych mnichów ze słynnego 22. Listu Hieronima, którzy tylko po to oddawali się ascezie, by zyskać dostęp do domów bogaczy i sypialni dziewic.

hac haeresi, quam Pelagius et Caelestius seminarunt, in Africa gestum esse cognoscerem, fideliter ac simpliciter indicarem".

${ }^{46}$ Tamże 31, 2, CSEL 5, 657: „Sed tibi specialis inde portandi oneris fortasse fiducia est, quod balneis epulisque nutritus latos humeros gestas robustamque cervicem, praeferens etiam in fronte pinguedinem, sicut scriptum est: tetendit enim adversum Deum manum suam et contra omnipotentem roboratus est".

${ }^{47}$ Por. tamże 12, 4, CSEL 5, 620: „Et nunc novus magister ministerque mensarum remissionem peccatorum de sua magis ausus est possibilitate praesumere, nec de Domino expectat audire!".

${ }^{48}$ Być może dwuznaczne sformułowanie, które znajduje się kilka linijek dalej, również zawiera aluzję to tej cechy portretowanego: ,inflatus spiritu carnis tuae" (tamże 13, 1, CSEL 5, 621).

${ }^{49}$ Por. tamże 29, 1-2, CSEL 5, 652: „Ita ista, inquam, ad Demetriadem puellam, ut audio, sacram et sanctam homo verecundissimus scribere non erubuisti, docens, ut credo, reverentiam castitatis sub stropha Ioseph et luxuriantis dominae suae, ubi dixisti, contempta frequenter domina propiores adulescenti tendit insidias, secretum ac sine testibus manu inpudens adprehendit, inopportunam historiam obscenissimo sermone contexens; quamquam hoc quod neque apte neque decore dicitur, tibi inputare non debeamus, cui neque natales dederunt, ut honestioribus studiis erudireris, neque naturaliter prouenit, ut saperes, sed illis dictatoribus tuis, qui miserum sensum miserrimo sermone conscribunt et te legendum cachinnis quasi titulum confusionis exponunt".

${ }^{50}$ Por. tamże 31, 6, CSEL 5, 658: ,sive nobilium episcoprum locorum episcopos videris sive potentes saeculi viros, sive divites sub religione videas". 
2. Podobieństwa. Napisane jeszcze w 415 r. pismo Liber apologeticus Orozjusza stanowi bezpośrednią odpowiedź na pierwszy sąd biskupi nad Pelagiuszem, który odbył się 28 lipca tegoż roku w Jerozolimie. Orozjusz broni w nim pozycji, jaką tam zajmował, zdaje relację z przebiegu przesłuchań i oskarża Pelagiusza i Celestiusza o herezję. Jako pierwszy potępia ich z imienia, a także łączy te dwa imiona, jako autorów nowej herezji; niewiele później uczyni to samo Augustyn.

Orozjusz używa podobnego argumentu jak biskup Hippony, kiedy sugeruje, że przeciw herezji Pelagiusza pisali już tacy nieżyjący autorzy, jak Cyprian, Hilary i Ambroży ${ }^{51}$. Z tego zaś wynika, że heretyk, chociaż głosi poglądy nowe, to dzięki przezorności Boskiej Opatrzności, zostały one już dawno potępione. Podkreśla też, że w momencie, kiedy on występuje przeciw Pelagiuszowi, także najwybitniejsi przedstawiciele Kościoła - Augustyn i Hieronim sprzeciwiają się jego naukom ${ }^{52}$. Również Hippończyk chętnie się chwali, że Hieronim jest po jego stronie, a mnich z Betlejem cieszy się z anty-pelagiańskich działań Augustyna.

Orozjusz używa również podobnych, konwencjonalnych metafor i przezwisk. Nazywa heretyka wężem, czyni go odpowiedzialnym za wydzielanie zatruwających powietrze wyziewów ${ }^{53}$. Do takiego samego porównania uciekł się Augustyn w swoim Sermo 348A z początku 416 r. oraz w 188. liście z 417 lub początku 418 roku $^{54}$. Tego typu argumentacja, oparta na metaforyce zwierzęcej, należała do konwencji tekstów antyheretyckich ${ }^{55}$.

Orozjusz sięga również po konwencjonalne wyzwiska, takie jak: mali${\text { gnus, } \text { caecus }^{56} \text {, servus nequam }}^{57}$, homo inflatus sed vacuus, pisze o jego caeca insania, profana temeritas ${ }^{58}$. Podobne epitety przypisane Pelagiuszowi znaj-

${ }^{51}$ Por. tamże 1, 4, CSEL 5, 604.

${ }_{52}$ Por. tamże 5, 1, CSEL 5, 609.

${ }^{53}$ Por. tamże 2, 1, CSEL 5, 604-605: „Contra hunc serpentem suffocantemque halitum multa utique beatissimi quos supra memoravimus uiri et multifaria suaveolentia scripturarum unguenta conficiunt et ad reficienda aestuantium corda populorum fragrantissimum thymiama cum oblatione orationis incendunt"; zob. też 1, 5-6.

${ }^{54}$ Por. Augustinus, Sermo 348A, 15; Epistula 188, 2.

${ }^{55}$ Por. I. Opelt, Die Polemik in der christlichen lateinischen Literatur von Tertullian bis Augustin, Heidelberg 1980, 154 i 162.

${ }^{56}$ Por. Orosius, Liber apologeticus contra Pelagianos 29, 5, CSEL 5, 653: „Caece et maligne - aliter enim tibi loqui nequeo, sensum dominicae auctoritatis, sensum propriae fragilitatis, sensum communis intellegentiae non habenti - nos naturam hominis infirmam dicimus esse, non malam".

${ }^{57}$ Por. tamże 30, 5, CSEL 5, 656: „Verumtamen tu, serve nequam et maligne, qui quod tibi dominus tuus remisit, $<\mathrm{a}>$ conservis tuis conaris exigere: tuum primum sensum discutio et meum postea si videtur explano".

${ }^{58}$ Por. tamże 30, 2, CSEL 5, 655: „Ait enim in epistula, quam supra nominavimus: verum e contrario remisso ac fastidioso animo superborum ac nequam servorum more in os Domini reclamamus, et dicimus «durum est, arduum est, non possumus; homines sumus, fragili carne circumdamur» et - o caecam insaniam! - et - o profanam temeritatem! - duplicis ignorantiae accusamus scientiae Dominum, ut videatur nescire quod fecit, nescire quod iussit et quasi oblitus fragilitatis humanae, 
dziemy też w pismach Augustyna, np. nefarius ${ }^{59}$, nefandus ${ }^{60}$, sceleratissimus $^{61}$. Orozjusz jednak znacznie częściej niż Augustyn korzysta z tak ostrych środków wyrazu, a jego język wydaje się bardziej gwałtowny, a przez to bliższy inwektywom Hieronima.

Jednymi z konstytutywnych wad heretyka są wytykane - głupota i pycha. Orozjusz, podobnie jak Augustyn, ukazuje nam Pelagiusza jako tego, który „nie ma pojęcia, ani o auctoritas Boga, ani o własnej znikomości i brak mu zdrowego rozsądku"62. Przedstawia go także jako pyszałka, kiedy zaleca mu, aby kochał wszystkich chrześcijan, jak siebie samego, zarzucając mu zbyt wybujałą miłość własną (amor sui $)^{63}$.

U Augustyna Pelagiusz jako heretyk jest tym, który nie potrafi stosować literackiej proprietas. Również Orozjusz wyposaża swojego przeciwnika w tę wadę. Wypomina Pelagiuszowi, że w Epistula ad Demetriadem wspomniał o historii Józefa uwodzonego przez jego panią, co nie było powiedziane ani apte, ani $\operatorname{decore}^{64}$. Nieco dalej wprowadza cytat $\mathrm{z}$ tego listu słowami:

„między innymi więc i tego rodzaju zdanie wyrzygałeś w tym liście swoimi niestrawionymi słowami”"65.

\section{PELAGIUSZ U MARIUSZA MERCATORA I AUGUSTYNA}

W pierwszej kolejności należy zauważyć, że oba pisma Mariusza Mercatora, przygotowane na sobór w Efezie, dotyczą przede wszystkim Celestiusza i Juliana z Eklanu: znamy je pod tytułami: Liber subnotationum in verba Iuliani ${ }^{66}$ oraz Commonitorium super nomine Caelesti ${ }^{67}$. Przeciw nim autor ten

cuius auctor ipse est, inposuerit homini, quod ferre non possit”. Typowy dla polemik antyheretyckich zarzut szaleństwa nigdy nie pojawia się pismach Augustyna przeciw Pelagiuszowi.

${ }^{59}$ Por. Augustinus, De gestis Pelagii 11, 25, CSEL 42, 79: ,iste nefarius”, ŹMT 12, 238.

${ }^{60}$ Por. Augustinus, De gratia Christi I 17, 18; De nuptiis et concupiscentia II 2, 4.

${ }^{61}$ Por. Augustinus, De natura et gratia 10, 11. Dobrą analizę pola semantycznego tych pojęć w ustawodawstwie antyheretyckim czytelnik znajdzie w: M. Stachura, Wrogowie porzadku rzymskiego. Studium zjawiska agresji językowej w Kodeksie Teodozjusza, Nowelach Postteodozjańskich i Konstytucjach Sirmondiańskich, Kraków 2010.

${ }^{62}$ Orosius, Liber apologeticus contra Pelagianos 29, 5, CSEL 5, 653: „sensum dominicae auctoritatis, sensum propriae fragilitatis, sensum communis intellegentiae non habenti”.

${ }^{63}$ Por. tamże 31, 7, CSEL 5, 659: „Utrum ergo sicut te ipsum diligas omnes, qui misericordiam Dei sperant, quos tamen noveris, confitere; non enim te de ignotis consulo, quos ex eo te diligere arbitraris, quod quia non noveris, non odisti".

${ }^{64}$ Por. tamże 29, 1-2, CSEL 5, 652; zob. wyżej n. 49.

${ }^{65}$ Tamże 29, 3, CSEL 5, 652: „,inter haec ergo huiusmodi sensum in eadem epistula indigestis sermonibus eructasti, quod plerique nostrorum dicerent, Deum malam hominis condidisse naturam".

${ }^{66}$ Por. Marius Mercator, Liber subnotationum sub verba Juliani (= Commonitorium I adversus haeresim Pelagii et Caelestii), PL 48, 109-172.

${ }^{67}$ Por. Marius Mercator, Commonitorium super nomine Caelestii (= Commonitorium II adversus haeresim Pelagii et Caelestii), PL 48, 63-108. 
znacznie częściej sięga po zarzuty a persona i elementy ostrej inwektywy. O Celestiuszu pisze, np. że już z łona matki wyszedł jako eunuch. Po drugie, przedstawienie przebiegu herezji, a zwłaszcza informacje o Pelagiuszu, są wyraźnie zależne od danych, które autor ten znalazł w pismach Augustyna, Orozjusza i Hieronima.

1. Różnice. Podobnie jak Hieronim i Orozjusz Mariusz Mercator uznaje Pelagiusza za kontynuatora starszej herezji, który jednak rozpropagował ją szerzej jako pierwszy publiczny nauczyciel. Mercator tworzy jednak inną genealogię pelagianizmu ${ }^{68}$. Nie dziwi nas to jednak, ponieważ takie łączenie herezji w genealogie służyło ortodoksyjnym pisarzom jako broń „obosieczna", którą można było dosięgnąć kilku wrogów za jednym zamachem. Mercator m.in. sugeruje, że pelagianizm wypływa z nauczania Teodora z Mopsuestii, bo ten pracowity i uczony egzegeta, należący do szkoły antiocheńskiej, miał nieszczęście być nauczycielem Nestoriusza. Ten z kolei był głównym oskarżonym na soborze w Efezie, na który dossier o kontrowersji pelagiańskiej przygotowywał Mercator. Celestiusz i Julian z Eklanum mieli prosić Nestoriusza, gdy ten był jeszcze biskupem Konstantynopola, o wstawiennictwo w swojej sprawie ${ }^{69}$.

2. Podobieństwa. Kiedy Mercator wspomina o pierwszym synodzie w Palestynie, który odbył się latem 416 r. w Jerozolimie, wzmiankuje o tym, że Pelagiusz wykpił się od wyroku skazującego za pomocą dwuznacznych odpowiedzi i zręcznego tłumaczenia kwestii spornych ${ }^{70}$. Sugeruje, że część

${ }^{68}$ Por. Marius Mercator, Comminotorium I 1-2, PL 48, 109A-111A: „Quaestio contra catholicam fidem apud nonnullos Syrorum et praecipuo in Cilicia a Theodore quondam episcopo oppidi Mopsuesteni iamdudum mota nunc usque penes paucos eorum admodum roditur nec ea palam profertur; sed ab ipsis qui de ea cornicantur, velut catholicis intra Ecclesias, interim retinetur. Progenitores videlicet humani generis, Adam et Evam, mortales a Deo creatos, nec quemquam posterorum sui praevaricatione transgressi laesisse; sed sibi tantum nocuisse, seque mandati reos apud Deum fecisse, alterum penitus nullum. Hanc ineptam et non minus inimicam rectae fidei quaestionem sub sanctae memoriae recordationis Anastasio Romanae Ecclesiae summo pontifice Rufinus quidam natione Syrus Romam primus invexit et, ut erat argutus, se quidem ab eius invidia muniens, per se proferre non ausus, Pelagium, gente Brittanum monachus tunc decepit eumque ad praedictam adprime imbuit atque instituit impiam vanitatem".

${ }^{69}$ Dobre sprawozdanie o tych wydarzeniach zob. L. Wickham, Pelagianism in the East, w: The making of orthodoxy. Essays in honour of Henry Chadwick, ed. R. Williams, Cambridge 2002, 200-213. O stosunku Cyryla do Pelagiusza pisze G.D. Dunn, Augustine, Cyril of Alexandria, and the Pelagian controversy, AugSt 37 (2006) 63-88, jego ustalenia budzą jednak kontrowersje. W najbliższym czasie w „Studia Patristica” zostanie opublikowany artykuł H. van Loona, dotyczący tych kwestii.

${ }^{70}$ Por. Marius Mercator, Commonitorium II 3, 4, PL 48, 100A: „Adhuc etiam Hierosolymis constitutus Pelagius, accusatus fuit apud synodum, et primo quidem tergiversando, ambiguis quibusdam se professionibus tegens, et prosequens dubia, vel respondens, illam tunc videtur episcoporum audientiam delusisse". 
poglądów ortodoksyjnych heretyk ten głosi tylko po to, aby podstępnie ukryć swoje błędy ${ }^{71}$. Mówiąc o Julianie, wspomina o licznych uczniach Pelagiusza i Celestiusza ${ }^{72}$. Jeden raz nazywa Pelagiusza impius ${ }^{73}$, innym razem jego herezję określa mianem impiissimi errores ${ }^{74}$.

Mercator charakteryzuje Pelagiusza zarówno jako człowieka bojaźliwego, sugerując, że swoje księgi darował tylko tym, których uznawał za przyjaciół, jaki i zuchwałego, kiedy odnotowuje, że ważył się on napisać Komentarze $e^{75}$. Zuchwałości również wymagało głoszenie poglądów, które nauczyciel Pelagiusza, Rufin z Syrii, głosił jedynie po cichu. Ta ambiwalencja w określaniu postawy Pelagiusza wobec niebezpieczeństwa, jest zauważalna również w pismach Augustyna ${ }^{76}$.

Zanim przejdę do sformułowania wniosków płynących $\mathrm{z}$ powyższych analiz, należy rozważyć wagę trzech spostrzeżeń. Po pierwsze, pisma Orozjusza i Hieronima datujemy na rok 415 . Zostały opublikowane przed synodem w Diospolis, który okazał się punktem zwrotnym w kontrowersji pelagiańskiej. W oczywisty sposób bieg wydarzeń pozwalał Augustynowi na urozmaicenie portretu Pelagiusza, co czynił w tekstach tworzonych od 416 roku. Druga, pozornie równie błaha obserwacja, nakazuje niemniejszą ostrożność w ferowaniu sądów. Objętość traktatów, listów i kazań Augustyna, w których szkicuje on portret Pelagiusza, jest znacznie większa niż tekstów Hieronima, Orozjusza i Mariusza Mercatora razem wziętych. Trzecia uwaga dotyczy Mariusza Mercatora: pisał on już po wyrokach skazujących Pelagiusza i Celestiusza w 418 r., znał dzieła antyheretyckie Augustyna, z którym korespondował ${ }^{77}$, a jego pisma były skierowane raczej przeciw Julianowi z Eklanum i Celestiuszowi, niż bezpośrednio przeciw Pelagiuszowi ${ }^{78}$. Jeśli zatem Pelagiusz jest sportretowany najpełniej właśnie u Augustyna, to niekoniecznie należy to przypisywać tylko jego kunsztowi, bo miał po prostu więcej miejsca i okazji, aby to czynić.

Wziąwszy pod uwagę te ograniczenia, i pozostając $z$ dala od zbędnej emfazy, należy zauważyć, że wśród wszystkich czterech polemistów, Augustyn wyróżnia się pewną elegancją. Pomimo tego, że sięga on również do języka inwektywy, czasem ostrego, konwencjonalnych porównań heretyka do węża czy

\footnotetext{
${ }^{71}$ Por. tamże II 4, PL 48, 104AB.

${ }^{72}$ Por. tamże II 5, 2, PL 48, 107A.

${ }^{73}$ Por. tamże II 3, 4, PL 48, 104B.

${ }^{74}$ Por. tamże II 5, 1, PL 48, 106A.

${ }^{75}$ Por. tamże I 1, 3, PL 48, 111A.

${ }^{76}$ Zuchwałość Pelagiusza i jego uczniów np. Augustinus, De gestis Pelagii 35,66; De gratia Christi II 17, 19; lękliwość: Augustinus, Epistula 217, 2; De gestis Pelagii 11, 26; De gratia Christi

${ }^{77}$ Por. Augustinus, Epistula 193.

${ }^{78}$ Pelagiusz najprawdopodobniej już wówczas nie żył.
} II 21, 24. 
diabła, lub nie stroni od ironii i satyry, to godne uwagi jest, że nie wyśmiewa pochodzenia czy wyglądu zewnętrznego Pelagiusza, jak to czynią Hieronim i Orozjusz. Co więcej, portret Pelagiusza autorstwa Augustyna przedstawia także postać najbardziej niebezpieczną i budzi w odbiorcach większe emocje niż bardziej przesadzone, wyraźniej konwencjonalne, a czasem sztuczne uwagi Hieronima, Orozjusza czy Mercatora. Wreszcie, portret Pelagiusza w dziełach Augustyna jest znacznie lepiej zintegrowany z treścią przypisywanych heretykowi nauk.

Wszyscy czterej autorzy byli zdania, że Pelagiusz stawia człowieka niemalże na równi z Bogiem i przyznaje jego woli całkowitą autonomię oraz możliwość trwania bez grzechu; trafnie więc Augustyn podkreśla pychę tego heretyka. Można oczywiście sugerować, że te poglądy wynikają z częstości kapieli i obżarstwa - jak twierdził Orozjusz, albo z chęci kontynuacji nauk pitagorejczyków i stoików - jak pisał Hieronim, ale wybór Augustyna wydaje się trafniejszy z dwóch względów: pycha, jak przekonywał, jest korzeniem wszystkich grzechów i stanowi zaprzeczenie podstawowej cechy chrześcijanina - pokory; biskup Hippony podkreślał ten fakt niemal w każdym piśmie. Konwencjonalny portret antycznego heretyka zawsze zawierał tę wadę, i również Hieronim, Orozjusz i Mercator przypisywali ją Pelagiuszowi. Czynili to jednak rzadziej, nie wysuwając jej przed inne jego wady. Po drugie, pycha jako miłość własnych poglądów, uniemożliwia właściwe odczytanie Pisma Świętego i motywuje chęć współzawodniczenia z Kościołem. Założenie, że pycha Pelagiusza stanowi motyw rozwoju błędnych poglądów, umożliwia zatem Augustynowi ich odrzucenie. Pycha stanowiła dobry punkt wyjścia do uzupełnienia portretu o kolejne charakterystyki: twórcy nowej herezji, nauczyciela wielu uczniów i niebezpiecznego wichrzyciela.

\section{PELAGIUS AS SEEN BY AUGUSTINE, JEROME, PAUL OROSIUS AND MARIUS MERCATOR - A COMPARATIVE STUDY}

\section{(Summary)}

This paper aims at presenting the pecularities of the image of Pelagius as a heretic in the anti-Pelagian works of Augustine, Jerome, Paul Orosius and Marius Mercator. The circumstances of every analyzed writing are taken under consideration, for the date of composition and the size of a given polemics matter and influence the rhetorical strategies of the writers. The analysis is based on two categories, namely the similiarities and the differences between the portrayal of Pelagius. The contents of these works are interpreted from the perspective of their rhetorical form and literary techniques inherent in them and not from the perspective of a historian of theology.

The analysis enables to conclude that Augustine's portrayal is the most coherent, persuasive an detailed of all the considered heretical images. It is also the 
most elegant, e.g. Augustine - contrary to all other three writers - refrains from deriding the physical features of Pelagius or his origins. The Augustine's Pelagius is presented as the most dangerous new heretic and the arguments a persona are best fitted with the theological layer of polemics. One must, however, bear in mind that Augustine's works against Pelagius are far more numerous and longer than any other writer's. 